\title{
Hukum ketenagakerjaan
}

\author{
Oleh : Nurfadillah
}

nurfadillahdilla29062002@gmail.comm

\begin{abstract}
Protection of labor law in general material contained in the Contituion of the Republic Indonesia 27 paragraph 2, and in chapter 67 verses 1 and 2 are contained in Law Number 13 of 2003 concerning employment. Understanding of employment law is a law that has been in codofied written in the book of the law of civil law, and some (possibly all more than the already codified) has not been codified, and scattered in various laws and regulations. Disabled workersalso have implications for the rule of law on the rights and oligations of the same, disabled workers and workers generally normal (non disabled). This can happen because the only employment law established to provide protection in accordance with the type and degree of disablity. Labour law is basically a set of rules governing the before and until the end of the employment relationship between the worker and the worker's employer to work. In other words, employment law has the scope of legal protection before entering the world of work beginning to the end of the employment relationship itself.
\end{abstract}

\begin{abstract}
Abstrak
Perlindungan Hukum dalam materi ketenagakerjaan secara umum terdapat dalam Undang-Undang Dasar Negara Republik Indonesia tahun 1945 pasal 27 ayat 2,dan didalam pasal 67 ayat 1 dan 2 yang terdapat dalam Undang-Undang Nomor 13 tahun 2003 tentang Ketenagakerjaan. Pengertian dari Hukum Ketenagakerjaan ialah merupakan hukum tertulis yang telah dikodifikasi dalam Kitab Undang-Undang Hukum Sipil dan sebagian lagi (kemungkinan sekali lebih banyak dari yang sudah dikodifikasikan) belum dikodifikasikan, dan tersebar dalam berbagai peraturan perundang-undangan. Tenaga kerja penyandang cacat juga membawa implikasi adanya kepastian hukum mengenai Hak dan Kewajiban yang sama Tenaga Kerja Penyandang Cacat dan Tenaga Kerja normal pada umumnya (bukan Penyandang Cacat). Hal ini dapat terjadi karena hukum
\end{abstract}

Ketenagakerjaan hanya dibentuk untuk memberikan Perlindungan sesuai dengan jenis dan derajat kecacatannya. Hukum Ketenagkerjaan pada hakikatnya merupakan seperangkat kaidah yang mengatur tentang sebelum dan sampai berakhirnya hubungan kerja antara pekerja dan perusahaan tempat pekerja tersebut bekerja. Dengan kata lain, Hukum Ketenagakerjaan mempunyai ruang lingkup Perlindungan Hukum dari awal sebelum memasuki Dunia Kerja hingga berakhirnya Hubungan Kerja itu sendiri. 


\section{Pendahuluan}

Ketenagakerjaan (perburuhan) adalah faktor produksi kedua yang akan diatur dalam sebuah perekonomian.Tenaga kerja bersama dengan faktor produksi yang lain yaitu lahan dan permodalan akan berperan penting dalam peningkatan produksi Oleh karena itu, jika sebuah perekonomian menginginkan agar dapat terus tumbuh dan berkembang, maka faktor tenaga kerja ini harus mendapat perhatian yang serius.Dalam ekonomi pasar bebas, permasalahan ketenagakerjaan senantiasa menimbulkan banyak problem yang seakan tak berujung pangkal Posisi tenaga kerja atau kaum buruh dalam ekonomi kapitalisme akan senantiasa tertindas.

Perjanjian Kerja adalah perjanjian antara pekerja/buruh dengan pengusaha/pemberi kerja yang memuat syarat-syarat kerja, hak dan kewajiban para pihak (Pasal 1 angka 14 UndangUndang Nomor 13 Tahun 2003 tentang Ketenagakerjaan). Ciri khas perjanjian kerja yaitu: 1. Perjanjian antara pekerja dengan pemberi kerja; 2 . Memuat syarat-syarat kerja; dan 3. Berisi hak dan kewajiban pekerja dengan pemberi kerja. Ciri-ciri lain dari perjanjian kerja adalah adanya atasan (yang memimpin) dan bawahan (yang dipimpin) serta adanya upah atau imbalan dalam bentuk lain yang diterima oleh bawahan dari pihak atasan. Buku Hukum Ketenagakerjaan ini diterbitkan oleh penerbit deepublish dan tersedia juga versi cetaknya.

\section{Pembahasan}

Ketenagakerjaan adalah segala sesuatu yang berhubungan dengan tenaga kerja pada waktu sebelum, selama dan setelah selesai masa hubungan kerja, baik pada pekerjaan yang menghasilkan barang maupun pekerjaan berupa. Dari aspek hukum ketenagakerjaan merupakan bidang hukum privat yang memiliki aspek publik, karena meskipun hubungan kerja dibuat berdasarkan kebebasan para pihak, namun terdapat sejumlah ketentuan yang WAJIB tunduk pada ketentuan pemerintah dalam artian hukum publik.

tenaga kerja antar Negara. Adapun yang mendorong kegiatan ekspor impor disebabkan karena tidak ada satu negara yang benar- benar bisa memenuhi semua kebutuhan warga nya dan setiap negara memiliki kaharakteristik yang berbeda, baik dari sunber daya alam, iklim, geografis, demografi, struktur ekonomi dan struktur social.

Hukum perdagangan internasional adalah bidang hukum yang berkembang cepat. Hubunganhubungan dagang yang sifatnya lintas batas terdapat banyak jenisnya. Dari bentuknya yang sederhana, yaitu dari barter, jual beli barang atau komoditi (produk-produk pertanian, perkebunan, dan sejenisnya), hingga hubungan atau transaksi dagang yang kompleks. Ada beberapa pendapat tentang defenisi di bidang hukum ini salah satunya Rafiqul Islam yang mendefinisikan "hukum perdagangan dan keuangan ("international trade and finance law") sebagai suatu kumpulan aturan, prinsip, norma dan praktek yang menciptakan suatu pengaturan (regulatory regime) untuk transaksitransaksi 
perdagangan transnasional dan sistem pembayarannya, yang memiliki dampak terhadap perilaku komersial lembaga-lembaga perdagangan

\section{Peraturan \& UU Ketenagakerjaan}

Berdasarkan Undang-Undang No.13 Tahun 2013 tentang ketenagakerjaan dijelaskan bahwa Ketenagakerjaan adalah segala sesuatu yang berkaitan dengan tenaga kerja baik pada waktu sebelum, selama dan sesudah masa kerja. Peraturan tersebut dilandasi dengan tujuan sebagai berikut:

1.Memberdayakan dan mendayagunakan tenaga kerja secara optimal dan manusiawi 2.Mewujudkan pemerataan kesempatan kerja dan penyediaan tenaga kerja yang sesuai dengan kebutuhan pembangunan nasional dan daerah

3.Memberikan pelindungan kepada tenaga kerja dalam mewujudkan kesejahteraan 4.Meningkatkan kesejahteraan tenaga kerja dan keluarganya

Pasal 5 UU 13/2013 menegaskan bahwa setiap tenaga kerja memiliki kesempatan yang sama untuk memperoleh pekerjaan tanpa adanya diskriminasi. Lebih lanjut, tenaga kerja dapat diklasifikasikan menjadi tiga kelompok yaitu:

\section{a. MoTenaga Kerja Terdidik}

Tenaga kerja yang mempunyai keahlian pada bidang tertentu atau khusus yang diperoleh dari bidang pendidikan. Sebagai contoh: dosen, dokter, guru, pengacara, akuntan dan sebagainya.

\section{b.Tenaga Kerja Terlatih}

Tenaga kerja yang memiliki keahlian pada bidang tertentu atau khusus yang diperoleh dari pengalaman dan latihan. Sebagai contoh: supir, tukang jahit, montir dan sebagainya.

\section{b. Tenaga Kerja Tidak Terdidik dan Tidak Terlatih}

Tenaga kerja yang mengandalkan tenaga, tidak memerlukan pendidikan maupun pelatihan terlebih dahulu. Sebagai contoh: kuli, pembantu rumah tangga, buruh kasar dan sebagainya.

Klasifikasi diatas mendorong pengaturan terkait pelatihan kerja sebagaimana diatur dalam Bab V UU 13/2013, agar kualifikasi tenaga kerja Indonesia dapat semakin baik.Dalam pelaksanaan ketenagakerjaan, pelaku usaha dan tenaga kerja mengikatkan diri dalam suatu hubunga hukkum melalui ikatan atau perjanjian kerja yang sudah disepakati oleh kedua belah pihak, bersifat tertulis atau lisan dan dilandasi sesuai dengan peraturan perundang-undangan ketenagakerjaan yang berlaku. Hak dan kewajiban antara pengusaha dan tenaga kerja juga menjadi perhatian demi menciptakan keamanan dan kenyamanan saat melakukan aktivitas pekerjaan.Apabila timbul perselisihan antara pengusaha dan tenaga kerja, maka hukum yang mengatur adalah Undang Undang No.2 Tahun 2004 tentang Penyelesaian Perselisihan Hubungan Industrial. Setiap bentuk perselisihan memiliki cara atau prosedur yang berlaku dan harus diikuti oleh kedua belah pihak baik itu melalui cara berunding, mediasi, konsiliasi, arbitrase maupun diselesaikan di Pengadilan Hubungan Industrial. 


\section{Masalah Ketenagakerjaan}

Masalah ketenagakerjaan dapat timbul karena beberapa faktor seperti pendidikan, kesempatan kerja maupun pertumbuhan ekonomi yang relatif rendah. Hal ini dialami oleh banyak negara yang termasuk Indonesia, karena hingga saat ini masih banyak pengangguran atau lebih tepatnya lagi orang yang tidak dapat bekerja karena minimnya lapangan pekerjaan.

\section{Sifat Hukum Ketenagakerjaan}

Hukum Ketenagakerjaan dapat bersifat perdata (privat) dapat bersifat publik.

Dikatakan bersifat karena sebagaimana kita ketahui bahwa hukum perdata mengatur kepentingan orang perorangan, dalam hal ini adalah antara tenaga kerja dan pengusaha, yaitu dimana mereka mengadakan suatu perjanjian yang disebut dengan perjanjian kerja.

Hukum Perjanjian sendiri terdapat/diatur di dalam Kitab Undang-Undang

\section{Hukum Perdata Buku ke-III.}

Disamping bersifat perdata juga bersifat publik (pidana), alasannya adalah:

a. Dalam hal-hal tertentu negara atau pemerintah turut campur tangan dalam masalah-masalah ketenagakerjaan, misalnya dalam masalah pemutusan hubungan kerja;

b. Adanya sanksi-sanksi atau aturan-aturan hukuman didalam setiap undangundang atau peraturan perundang-undangan di bidang ketenagakerjaan.

Sumber-sumber hukum yang terpenting secara umum dan mendasar yaitu:

a. Perjanjian-perjanjian internasional yang sudah diratifikasi oleh pemerintah

Republik Indonesia

b. Undang-undang Dasar 1945

c. Perundang-undangan untuk hal-hal khusus

d. Peraturan dan Keputusan Menteri

e. Kesepakatan kerja bersama 
f. Presiden (putusan-putusan terdahulu dari pengadilan)

g. Perarturan Kerja yang ditetapkan perusahaan

h. Perjanjian kerja individual

i. Instruksi oleh majikan/pemberi kerja

j. Doktrin hukum

Pendapat yang ditambahkan dari Aisikin dan Wahab bahwa salah satu sumber hukum ketenagakerjaan yaitu pendapat dari para ahli hukum. Hal ini karena dapat dipergunakannya pendapat para ahli hukum sebagai landasan untuk pemecah konflik-konflik dalam perselisihan perburuhan secara langsung ataupun secara tidak langsung.

Abdul khakim berpendapat adanya penambahan agama masuk sebagai sumber hukum ketenagakerjaan, karena adanya kemungkinan terjadinya jalan keluar atau pemecahan konflik ketenagakerjaan dengan jalur pendekatan agama yang dianutnya

\section{PROBLEM PERBURUHAN (KETENAGAKERJAAN)}

- Untuk menyelesaikan problem ketenagakerjaan, maka kita harus mampu melihat apa yang menjadi akar dari masalah ketenagakerjaan.

- Permasalahan yang krusial dalam ketenagakerjaan adalah menyangkut pemberian kompensasi atau upah yang harus diberikan oleh pihak yang mempekerjakan kepada pihak yang dipekerjakan.

Masalah inilah yang dapat menimbulkan konflik yang berkepanjangan antara pekerja dan pemberi kerja, sehingga membutuhkan pengaturan dan penataan lebih lanjut dengan hukum-hukum tertentu.

- Sedangkan masalah yang lain, seperti keselamatan kerja, cuti kerja, etos kerja, keterampilan kerja, layanan kerja, dll., dapat dianggap sebagai masalahn turunan dari persoalan dunia ketenagakerjaan.

PANDANGAN EKONOMI KAPITALISME 
- Posisi kaum buruh dalam ekonomi kapitalisme hanya akan ditempatkan sebagai salah satu komponen faktor produksi.

- Konsekuensi dalam rangka untuk mendapatkan keuntungan yang setinggi-tingginya, maka ulah buruh sebagai salah satu faktor produksi harus ditekan serendah rendahnya.

- Dari sinilah kemudian muncul istilah hukum upah besi, yaitu upah buruh tidak dapat dinaikkan dan tidak dapat diturunkan.

- Upah buruh akan tetap bertengger pada posisi untuk sekedar pemenuhan kebutuhan fisik minimum (KFM)-nya saja.

\section{PANDANGAN EKONOMI SOSIALISME}

- Menurut sosialisme,kaidah ketenagakerjaan yang adil adalah :

- " pekerjaan bagi pekerja itu sesuai dengan kemampuan atau kesanggupannya sedangkan upah bagi pekerja itu sesuai dengan kerjanya."

- sosialisme memandang bahwa kerja dari seorang pekerja merupakan asas yang paling utama dalam produksi barang.

- upah untuk seorang pekerja akan ditentukan berdasarkan barang yang diproduksinya. Sedangkan seluruh biaya produksi akan dikembalikan kepada satu unsur saja yaitu kerja.

- akibatnya, peran pemikiran yang strategis tidak diangggap penting karena semua sudah diperankan oleh Negara.

\section{Tiga masalah ketenagakerjaan yang sering terjadi di Indonesia:}

1. Banyaknya Pengangguran

Disebabkan karena tingginya jumlah penduduk dan tidak diikuti dengan lapangan kerja yang cukup, permasalah ini merupakan yang paling utama di Indonesia. Begitu juga dengan rendahnya kualitas tenaga kerja dan pertumbuhan ekonomi yang menjadi faktor utama dalam timbulnya masalah ini.

2. Lapangan Kerja yang Rendah

Timbul akibat jumlah angkatan kerja yang produktif tidak sebanding dengan jumlah lapangan kerja yang disediakan. Hal ini menjadi salah satu pemicu masalah pengangguran.

3. Kualitas Tenaga Kerja yang Rendah

Tingkat pendidikan yang rendah baik formal maupun non formal. Kemampuan ekonomi masyarakat Indonesia tergolong rendah menyebabkan ketidakmampuan untuk meraih pendidikan yang tinggi. 
Bicara tentang ketenagakerjaan tentunya masih banyak lagi yang dapat dijadikan pembahasan. Sekilas pemaparan secara umum mengenai pengertian, peraturan dan masalah ketenagakerjaan yang ada di Indonesia.

. Subjek dan Objek Hukum Ketenagakerjaan

a. Subjek Hukum Ketenagakerjaan

1) Pekerja

"Pekerja adalah tenaga kerja yang bekerja di dalam hubungan kerja pada pengusaha dengan menerima upah." (Pasal 1 Angka 3 UU Nomor 25 Tahun 1997 Tentang Ketenagakerjaan). "Pekerja (2) adalah setiap orang yang bekerja dengan menerima gaji, upah, atau imbalan dalam bentuk lain." (Pasal 1 Angka 11 UU Nomor 40

Tahun 2004 Tentang Sistem Jaminan Sosial Nasional). "Pekerja (3) adalah setiap orang yang bekerja dengan menerima gaji, upah, atau imbalan dalam bentuk lain." (Pasal 1 Angka 8 UU Nomor 24

Tahun 2011 Tentang Badan Penyelenggara Jaminan Sosial). "Pekerja (4) adalah setiap orang yang bekerja dengan menerima upah atau imbalan dalam bentuk lain sesuai dengan ketentuan peraturan perundang-undangan." (Pasal 1 Angka 4 UndangUndang Nomor 4 Tahun 2016 tentang Tabungan Perumahan

Rakyat).

Pekerja atau buruh adalah setiap orang yang bekerja dengan menerima upah atau imbalan dalam bentuk apapun. Pengertian mengenai pekerja tersebut diatur dalam pasal 1 angka (4) UndangUndang No. 13 Tahun 2003 Tentang Ketenagakerjaan. Pengertain yang dimaksud dalam UU diatas merupakan pengertian yang umum dan maknanya luas, itu berarti pekerja adalah semua orang yang bekerja kepada siapa saja, baik itu kepada perorangan, kepada badan hukum atau badan lainnya dengan menerima imbalan atau upah dalam berbagai bentuk apapun. Upah atau imbalan dalam berbagai bentuk apapun dalam pengertian tersebut perlu ditegaskan, karena selama ini upah slalu diidentikkan dengan uang, padahal penerimaan upah atau imbalan yang diterima pekerja ada juga yang berbentuk barang, itu artinya penerimaan upah atau imbalan yang diterima pekerja tidak slalu dalam bentuk uang.

$$
\text { Sudikno Mertokusumo dalam bukunya yang berjudul }
$$

Mengenal Hukum Suatu Pengantar, terdapat salah satu hak yaitu Hak relatif yang didalamnya berisi aturan mengenai hak seseorang untuk menuntut atau menagih haknya. Kewajiban adalah batas dan beban dalam melakukan sesuatu, artinya bahwa Pengusaha 
dan Pekerja mempunyai hak yang harus didapatkan dan kewajiban yang masing-masing harus dipenuhi.

Hak pekerja adalah serangkaian Hak Asasi Manusia (HAM) dan sekumpulan hak yang diatur dalam perundang-undangan yang berkaitan dengan hubungan pekerjaan antara si pekerja dengan pengusahanya. Hak pekerja tersebut selalu didapat atau diperoleh dari Undang-undang yang mengatur pekerja atau buruh. Secara umum didalam Undang-undang tersebut mengatur tentang hak pekerja yang berhubungan dengan perundingan gaji, kemanfaatan, dan keselamatan pekerja. Salah satu hal yang utama didalam hak pekerja yaitu hak untuk membentuk sebuah persatuan.

Perundingan pekerja secara berkelompok atau kolektif diperbolehkan dalam suatu persatuan kerja dengan pengusaha, hal tersebut bertujuan untuk meningkatkan upah atau gaji ahli dan peningkatan keadaan tempat pekerja dengan yang lebih baik.

Hak pekerja tersebut, pekerja juga diperbolehkan pengurusan atau pengawalan pekerja dengan pemberian hak kepada pekerja untuk menentukan suara dalam suatu keputusan dasar.

2). Pengusaha

Pengusaha adalah setiap orang yang menjalankan perusahaan, dengan memberikan pekerjaan kepada orang lain dan pemberian imbalan dalam bentuk upah atas pekerjaan yang telah dilakukan oleh si pekerja.

3). Organisasi Buruh atau Serikat Pekerja

Organisasi buruh atau serikat pekerja merupakan alat utama bagi buruh atau pekerja yang berfungsi sebagai pelindung dan untuk memperjuangkan kedudukan pekerja dalam memperbaiki Nasib.

\section{b. Objek Hukum Ketenagakerjaan}

Objek Hukum Ketenagakerjaan yaitu segala sesuatu yang menjadi tujuan diberlakukannya Hukum Ketenagakerjaan.

Yang menjadi objek Hukum Perburuhan:

1). Sanksi hukum yang terlaksana dengan baik yang bersifat administratif maupun sanksi pidana akibat dari pelanggaran ketentuan yang diatur dalam Undang-undang.

2). Ganti rugi yang terpebuhi bagi pihak yang dirugikan, akibat dari adanya wanprestrasi atau ingkar janji yang dilakukan oleh pihak lain, dalam perjanjian yang telah disepakati sebelumnya. 
4. Ruang Lingkup Hukum Ketenagakerjaan

Logemann berpendapat bahwa lingkup berlakunya suatu hukum ialah suatu bidang atau keadaan dimana kaidah hukum itu berlaku.

Ada 4 lingkup Laku Hukum berdasarkan teori tersebut, antara lain :

\section{a. Lingkup Laku Pribadi}

Hal ini berhubungan erat dengan apa atau siapa yang dibatasi oleh kaidah suatu hukum. Siapa saja pihak-pihak yang dibatasi oleh kaidah hukum yang mengatur mengenai ketenagakerjaan atau suatu hukum yang mengatur perburuhan, ialah :

1) Perusahaan atau Pengusaha

2) Pekerja atau Buruh

3) Pemerintah atau Penguasa

b. Lingkup Laku Menurut Wilayah

Berkaitan dengan suatu kejadian atau peristiwa hukum yang oleh kaidah hukum dibatasi.

c. Lingkup Laku Menurut Waktu

Mengenai pengaturan mengenai kapan waktu suatu peristiwa atau kejadian tertentu diatur oleh kaidah hukum.

\section{d. Lingkup Waktu Menurut Hal Ikhwal}

Berhubungan dengan suatu apapun dari kaidah jika hal tersebut menjadi objek pengaturan.

Undang-Undang Nomor 13 tahun 2003 diterangkan bahwa hukum Ketenagakerjaan adalah sekumpulan peraturan tentang segala hal yang berkaitan dengan tenaga kerja pada waktu sebelum, selama, dan sesudah masa kerja.

Dari pengertian tersebut diketahui bahwasanya hukum ketenagakerjaan meliputi 3 hal yaitu :
a. Sebelum masa kerja
b. Selama masa kerja 
c. Sesudah masa kerja

Undang Undang Ketenagakerjaan kita mengacu pada pengertian hukum

Ketenagakerjaan yang lebih luas ditinjau dari hal tersebut.

5. Sumber Hukum Ketenagakerjaan

Hukum Ketenagakerjaan atau Hukum Perburuhan terbagi ke dalam tiga bagian:

a. Hukum Hubungan Kerja Perseorangan (Individual Employment

Law);

b. Hukum Perburuhan Berkelompok (Collective Labour Law);

c. Hukum Jaminan Sosial (Social Security Law), yang behubungan dengan pembahasan diatas.

Kepustakaan Indonesia di dalamnya tercantum bahwa Hukum Perburuhan dibagi kedalam 3 peraturan, yaitu Undang-undang No. 13 Tahun 2003 Tentang Ketenagakerjaan, Undang-undang No. 21 Tahun 2000 Tentang Serikat Pekerja atau Serikat Buruh, dan Undang-undang No. 2 Tahun 2004 Tentang Penyelesaian Perselisihan Hubungan Industrial atau biasa disingkat PPHI.

\section{Penutup}

Yang wajib di laksanakan oleh setiap pengusaha atau perusahaan yang mempekerjakan orang untuk bekerja.Para perusahaan tersebut harus sangat di perhatikan, yaitu mengenai pemeliharaan dan peningkatan kesejahteraan di maksud di selenggarakan dalam bentuk jaminan sosial tenaga kerja yang bersifat umum untuk dilaksanakan atau bersifat dasar, dengan bersaskan usaha bersama, kekeluargaan dan kegotong royangan. 


\section{Daftar Pustaka}

Yogi Aditiya, 2004 (hukum ketenagakerjaan)

Jakarta.

Agusmidah. 2010. Dinamika dan Kajian Teori.

Bogor. Ghalia Indonesia. Hlm. 5. 